\title{
Investment Behaviour and Capacity Adjustment in Fisheries: A Survey of the Literature
}

\author{
LINDA NØSTBAKKEN \\ University of Alberta and \\ SNF \\ OLIVIER THÉBAUD \\ CSIRO Marine and Atmospheric Research and \\ UMR AMURE, Ifremer Centre de Brest

\section{LARS-CHRISTIAN SØRENSEN University of Copenhagen}

\begin{abstract}
This article provides a survey of the economic literature on investment behaviour and capacity adjustment in fisheries. An overview of the existing theoretical and the empirical work is provided, and areas that require more work are pointed out. The survey shows that while a large body of theoretical work has been developed on the issue of capital adjustment in fisheries, relatively less attention has been granted to the theory of investment, where this becomes a separate decision to the decision about capital levels; i.e., where capital is quasi-malleable. In addition, empirical studies have been fairly limited, and more work is still needed to analyse and further investigate these issues in practical situations. There is particularly a need for more empirical studies of investment behaviour and drivers of investment behaviour at the firm level based on adequate economic data.
\end{abstract}

Key words Investment, capital adjustment, capacity, ITQs, fisheries.

JEL Classification Code Q22.

\section{Introduction}

Investment can be defined as the change over time in capital stocks. While investment appears a key to understanding past changes and possible futures of marine fisheries, scholars have recently stressed that it is still poorly understood (Garcia and Grainger 2005; Munro 2010). This may be partly due to the fact that while the theory of capital in the fishery is now well established, research on capital dynamics in this sector has, to some extent, proceeded as if capital stocks entailed only variable costs; in other words as if capital invested in marine fisheries could be considered perfectly malleable (Burt and Cummings 1970; Munro 2010). Under such circumstances, levels of capital and invest-

Linda Nøstbakken is an assistant professor, Alberta School of Business, University of Alberta, 2-32D Business Building, Edmonton, Alberta, T6G 2R6, Canada and Institute for Research in Economics and Business Administration (SNF), Bergen, Norway (email: Linda.Nostbakken@ualberta.ca). Olivier Thébaud is a research scientist, CSIRO Marine and Atmospheric Research, PO Box 2583, Brisbane, QLD, 4001, Australia and UMR AMURE, Ifremer Centre de Brest, France (email: Olivier.Thebaud@csiro.au). Lars-Christian Sørensen is a research assistant, Institute of Food and Research Economics (FØI), University of Copenhagen, Rolighedsvej 25, 1958 Frederiksberg C, Denmark.

We are thankful to two anonymous referees and an associate editor for comments. All remaining errors and omissions are our own. Financial support from the European Commission is gratefully acknowledged (the 6th Framework Project: CAFE-Measurement of Capacity, Effort and Fishing Mortality). 
ment become essentially equivalent problems. However, as stressed by Munro (2010), the more common situation in marine fisheries is for capital to have a degree of non-malleability such that the basic bioeconomic theory of capital in the fishery is inapplicable. Where capital is not perfectly malleable, capital levels and the rate at which these change become separate but related decisions, lead to a greater degree of complexity and to the need for a separate theory of investment. In addition, while the key role of the firm's investment behaviour in the evolution of fisheries is now widely recognised, empirical studies of capital changes in ocean fisheries and the micro-economic drivers of these changes have only developed recently and still remain relatively scarce.

Past reviews of the literature on investment in marine fisheries have focused on the conceptual framework of capital theory in a sector harvesting a renewable resource (Munro 1998; Gréboval and Munro 1999; Charles 2007). In this survey, we provide a synthesis of the key elements of this conceptual framework and focus on reviewing empirical studies that have attempted to apply this framework with the objective of providing a basis for identifying current perspectives for future research. Our purpose is to give an overview of the main areas that have been considered, in terms of both the questions addressed and the approaches used. Rather than providing a complete survey of the literature, we use selected articles to illustrate what we believe are the main lines of investigation that have been explored to date and those that could be pursued further, particularly from an empirical perspective. In particular, our review of the empirical literature shows that further research is required on the determinants of investment strategies into the different components of capital in fisheries, including physical capital, natural capital, human capital, and access rights to fish resources.

The article is structured as follows. The first section provides a brief summary of the theoretical literature on investment in fisheries. The second section considers empirical studies of investment and capacity adjustment in capture fisheries. Section three concludes by discussing the implications of the survey in terms of current research perspectives.

\section{Theoretical Models of Investment Behaviour}

Conceptual studies of capital dynamics in marine fisheries have taken one of two alternative stands. Some have centred on the determination of optimal investment paths towards desirable levels of capital stocks and have usually been applied to an entire fishery, considering that it could be managed by a single owner acting to benefit society. Others have focused on the incentives created by economic and regulatory circumstances under which fishing firms operate and the resulting investment behaviour leading to changes in capital stocks.

The approach taken has, to some extent, influenced the categories of capital considered in these studies. Four distinct types of capital can be encountered in economic studies of marine fisheries: natural, physical, human, and immaterial. By definition, natural capital in the form of commercial fish stocks cannot be produced by man, but is available to fishing firms as a result of the functioning of marine ecosystems. Physical capital encompasses equipment and infrastructure that is required for the operation of fishing activities, while human capital relates to labour inputs needed to catch and process fish (e.g., skilled crews). We use the term immaterial capital to reflect the need for fishing firms to own fishing rights in contexts where access to fisheries is regulated. The focus of sole-owner type models is on optimal harvesting and optimal capital investment at the scale of a fishery, and hence, the influence of such fishing rights on investment patterns has usually not been considered in these models. In addition, these models have granted relatively little attention to human capital and issues of investment therein. Shifting the focus from a sole-owner perspective to a context where multiple firms make investment decisions in response to incentives created by the economic and regulatory circumstances in which they operate opens the possibility for immaterial capital to also be considered. 
Munro (2010), ze of non-mal$\mathrm{s}$ inapplicable. $h$ these change xity and to the 3 of the firm's ised, empirical ivers of these

focused on the 'esource (Munide a synthesis empirical studting a basis for an overview of addressed and srature, we use ;ation that have $y$ from an emws that further ifferent comporan capital, and

iummary of the iders empirical three concludes spectives.

f two alternative $\mathrm{s}$ towards desirery, considering have focused on ich fishing firms stocks. of capital coned in economic By definition, 1 by man, but is stems. Physical he operation of itch and process need for fishing ated. The focus ivestment at the sstment patterns is have granted in. Shifting the aake investment y circumstances , be considered.
This is the case if fishing rights, such as transferable quotas or effort units, are required to operate in a fishery. At this scale, however, the firms will usually not have a real option to invest in natural capital, since they may be too small to have a noticeable impact on fish stock size. Instead, the fishery manager typically decides on investment in natural capital through the choice of quotas and other regulations, while fishing firms will take this as given and act on levels of physical capital, human capital, and immaterial fishing rights.

Below, we discuss the existing theoretical work on investment in fisheries. We start out by reviewing studies that have considered the existence of a sole owner. Later, we turn to studies of investment behaviour that include an evaluation of the impacts of regulations on firm-level decisions; in particular, where these regulations pertain to the definition of access rights.

\section{Models of Optimal Investment Paths}

The seminal work on investment theory in fisheries was developed in the late 1960 s by Smith (1968) and during the 1970s by Clark, Clarke, and Munro (1979). Clark, Clarke, and Munro (1979) combined the previous work of Clark and Munro on the use of capital theory to analyse investment in natural capital with theories of investment in physical capital, particularly focusing on the irreversibility of fishing capital (Clark and Munro 1975; Clark 1976). In this section, we start out by providing a brief introduction to the model of Clark, Clarke, and Munro (1979) before presenting some of the subsequent theoretical work on physical investment in fisheries.

The model of Clark, Clarke, and Munro (1979) is based on a standard bioeconomic model of a single species fishery operated by a sole owner seeking to maximise the net present value of the fishery. The dynamics of the fish stock are given by:

$$
\dot{X}=F(X(t))-q E(t) X(t),
$$

where $F(X)$ is the natural growth function of the stock, which depends on the stock size $X$, and $q E X$ represents the harvest rate $h(t) . h(t)=q_{0} E(t) X(t)$ is known as the Schaefer production function, with $q_{0}$ representing a (constant) catchability coefficient and where $E(t)$ is total fishing effort at time $t$.

Physical capital is introduced to the Clark, Clarke, and Munro (1979) model as a limit on the effort available at time $t$. This constrains fishing effort to $E(t) \in[0, K(t)]$, where $K(t)$ is the capital stock at time $t$. Capital dynamics follow the investment model presented above; i.e., with $\dot{K}(t)=I(t)-\delta K(t)$.

The objective function of the sole owner can then be stated as follows:

$$
V=\int_{0}^{\infty} e^{-\rho t}\{p h(t)-w E(t)-\phi(I(t))\}
$$

where $\rho$ is the discount rate, $p$ is the output price, $w$ is the operating cost per unit effort, and $\phi(I(t))$ is the price of capital. This function is maximised over the control variables $E(t)$ and $I(t)$, subject to dynamic constraints on physical capital and fish stock dynamics.

Clark, Clarke, and Munro (1979) analyse three different cases, varying only in the assumed degree of malleability of physical capital. When physical capital is perfectly malleable, there is no constraint on investment: $I(t) \in[-\infty, \infty]$. In addition, it is assumed that the purchase price and the disposal price of capital are identical: $\phi(I)=c$. 
In this case, the stock variable, $K$, can be eliminated from the model, and the problem reduces to the problem dealt with in Clark and Munro (1975). With perfectly malleable capital, the capital level can be increased and decreased at a constant capital cost, and the problem becomes linear both in investment and effort. In this case, the optimal solution is the so-called "bang-bang approach" to the optimal biomass level. The other cases considered are perfectly non-malleable capital $(I(t) \geq 0$ and zero depreciation $\delta=0$ ), quasi-malleable capital $(I(t) \geq 0$ and depreciation $\delta>0)$, and a situation where there is a market for second-hand physical capital $\left(\phi\left(I^{+}\right)>\phi\left(I^{-}\right)\right.$, where $I^{+}>0$ and $\left.I^{-}<0\right)$. A key result obtained is that if fishing capital is quasi-malleable, the optimal restoration of an overexploited fish stock is a gradual approach to the optimal long-run biomass level. The optimal adjustment of fleet capacity will be gradual, rather than the most rapid approach that results under the assumption of perfect malleability.

Hence, while the main conclusion of Clark, Clarke, and Munro (1979) is that the optimal long-run equilibrium is unaffected by the degree of malleability of capital, their analysis shows that short-run optimal policies are significantly affected by this. In particular, the authors find that the less malleable physical capital is, the more it becomes necessary for a fish stock to be severely depleted before "extreme policies of stock rehabilitation" (e.g., fishing moratoria) can be optimal. Furthermore, the authors conclude that while excessive capitalization may develop in fisheries due to the common-pool status of fish resources, quasi-malleability of physical capital may also justify a degree of overcapitalization in a fishery.

Boyce (1995) extends the work of Clark, Clarke, and Munro (1979) by allowing both the investment cost function $\phi(I)$ and the net harvesting revenues (harvesting revenues minus harvesting costs) to be non-linear. Under these assumptions, the bang-bang approach is no longer optimal. Instead, a gradual approach to optimal capital levels is desirable. The model is further extended by Sandal, Steinshamn, and Hoff (2007), who introduce fixed costs of capital; that is, there is a cost of keeping capital whether it is utilised or not. The authors also replace the non-negative constraint on investment from the non-malleable capital assumption with a convex investment cost function (or revenue if disinvesting). With these model modifications, their objective function depends both on the resource and capital stocks. The convex investment cost and fixed capital cost lead to more conservative resource utilisation. In addition, the approach paths toward the optimal steady state changes and over- or undershooting may occur; that is, increase (decrease) in a state variable may occur even if the current state is above (below) the steady state level. This occurs as a result of the convexity of investment costs and the downward sloping demand function. A rapid reduction of the fish stock is suboptimal because high harvest levels yield a lower output price, while the convexity of the investment cost function makes fast reduction of capital levels suboptimal (undershooting).

Other related work includes Kennedy (1989), who analyses capacity and optimal harvesting policies in a multi-cohort model with initial excess capacity. The author considers adjustment paths to optimal steady state harvests that involve zero investment in the initial time periods while existing physical capital is being depreciated, followed by periods of investment to replace depreciating initial capacity when such investment becomes economically warranted. Botsford and Wainwright (1985) also explored the implications for optimal investment policies of biological models that include size structure and explicit density-dependence processes, when it is assumed that there are fixed costs of physical capital. Their analysis shows that when these costs are high enough, the optimal policy may be a constant policy.

The issue of capital market imperfections has received much attention in the general economic literature on physical investment. This issue is also highly relevant to investment in fisheries. Jørgensen and Kort (1997) analyse capital investment policies in renewable resource harvesting under a borrowing/lending constraint. They focus on

a soledecisio interes 1 a smal until th its fish ficientl along v maintai

fisherie optimal determi fort. $\mathrm{Tr}$ variabil functiol

where identica around on this,

A and Do stock gi ly, simi differ, stock gr particul ibility e lead to $\mathrm{i}$

Models

Thus fa assumpt understa fect cap. to the re maximi: also con 1954; S link the with suc and $R e v$ ment in entry an the antic 
and the problem rfectly malleable capital cost, and the optimal solu.. The other cases reciation $\delta=0$ ), 1 where there is a ad $\left.I^{-}<0\right)$. A key restoration of an iomass level. The st rapid approach

$1979)$ is that the $y$ of capital, their $d$ by this. In parmore it becomes ies of stock rehaiors conclude that lon-pool status of a degree of over-

779) by allowing s (harvesting revis, the bang-bang I capital levels is Hoff (2007), who whether it is utirestment from the on (or revenue if depends both on apital cost lead to sward the optimal ease (decrease) in steady state level. ownward sloping ause high harvest ent cost function

$r$ and optimal hara author considers stment in the inilowed by periods ent becomes ecoe implications for cture and explicit costs of physical he optimal policy

intion in the genighly relevant to vestment policies it. They focus on a sole-owner fishery and model the firm's harvesting, capital investment, and financing decisions. This represents an extension of Clark, Clarke, and Munro (1979) since the interest rate on debt is now increasing in cumulative debt. Jørgensen and Kort find that a small firm in terms of equity that starts out with a small fish stock does not harvest until the fish stock reaches a threshold level. In the meantime, the firm should dispose of its fishing capital and invest in financial assets. When the resource stock becomes sufficiently large, all financial assets are sold and the proceeds are invested in fishing capital along with additional borrowed funds. When the optimal steady state is reached, the firm maintains the stock at a constant level.

Another strand of the literature focuses on the introduction of uncertainty to the fisheries investment model, as fluctuations in stock size and catch quotas also affect the optimal level of fishing capacity. This is addressed by Hannesson (1987) who shows how deterministic models may give inadequate guidelines for optimal capacity and fishing effort. The author stresses the importance of explicitly taking into account environmental variability in fishery models. This can be done by adding a stochastic term to the growth function in the stock dynamics equation (1), which results in the following:

$$
\dot{X}=F(X(t)) z(t)-q E(t) X(t)
$$

where $z$ is a stochastic variable with mean one. In expected terms, stock dynamics are identical to those of the deterministic model presented above. However, the variation around the expected value can have implications for optimal investment paths. For details on this, see work by Charles $(1983,1985)$ and Hannesson (1993).

A recent study of investment under stock growth uncertainty is Singh, Weninger, and Doyle (2006). The authors develop a discrete-time model of a fishery with stochastic stock growth and costly capital adjustment. A stochastic variable is added multiplicatively, similar to what was shown in equation (3). The purchase and resale prices of capital differ, with $\mathrm{c}^{+}>\mathrm{c}^{-}$. They find that capital investment is only undertaken in periods when stock growth is particularly good, whereas disinvestment is only optimal in periods with particularly bad stock growth. Furthermore, the authors find that costly investment reversibility entails incentives towards the smoothing of harvest over time. This, in turn, may lead to increased variability in stock size.

\section{Models of Investment Behaviour}

Thus far, we have focused on studies that analyse optimal investment paths under the assumption of a sole owner. A second set of studies has placed greater emphasis on the understanding of the drivers of micro-economic investment behaviour and how these affect capital dynamics at the scale of a fishery. These studies usually grant specific attention to the regulatory context in which a fishing firm operates, since this affects the firm's profit maximization problem and its investment decisions and capital level. The studies often also consider how modifying this may affect the incentives faced by firms in a fishery.

Early economic models of marine fisheries typically assumed an open-access system where changes in the number of vessels followed the profitability of the fishery (Gordon 1954; Scott 1955). Dynamic models of entry and exit were then developed that directly link the entry and exit of vessels in a given fishery to the economic incentives associated with such choices (e.g., Smith 1968, 1969; Mackinson, Sumaila, and Pitcher 1997; Pascoe and Revill 2004). Smith $(1968,1969)$ introduced explicit representation of capital investment in his model of a fishery, focusing on the open-access regime, and he showed how entry and exit depend on current economic incentives in the fishery, defined in terms of the anticipated levels of returns associated with the prosecution of a given fishery, net of 
opportunity costs. Mackinson, Sumaila, and Pitcher (1997) analysed the implications of different catchability models on harvesting and stock collapse under the assumption that investment and disinvestment depend on current profits. Eisenack, Welsch, and Kropp (2006) provide an analysis of physical and natural capital dynamics in an open-access fishery with non-linear investment costs and stock-dependent harvesting costs. They use qualitative simulation and find that the development of excess capacities is unavoidable in such a model. In a developing fishery, the physical capital stock continues to grow for a period even after the harvest has started to decline due to the reduction in fish biomass. They find that this overcapitalisation period occurs as a result of the partial substitutability between physical and natural capital in the production process which they assume.

Later work focused on the fact that exit of vessels from a fishery can be difficult, as there may be few alternative opportunities (Ikiara and Odink 1999). Sumaila (1995) models investment and harvesting in a non-cooperative, two-player fishery game under the assumption of irreversible investment. He analyses a fish stock harvested by two fleets. In the first stage, the fleets determine their capacity level (investment), and in the second stage, they determine harvest levels. Sumaila (1995) characterises the Nash equilibrium and the sole-owner outcome. Not surprisingly, non-cooperation drives the stock far below the collectively optimal levels that would occur under a cooperative solution.

McKelvey (1985) extends the model by Clark, Clarke, and Munro (1979) to allow for convexities in costs, prices, and the production function. The author uses his model to analyse open access and the sole-owner case under the assumption of irreversible investment. He assumes individual firms consider expected future returns when making investment decisions. The open-access outcome deviates from the socially optimal solution because of the well-known stock externality. This leads to excessive capital investment and excessive harvest early on. It later leads to depleted stock levels, low harvest, and no net return to investment. McKelvey then examines the potential for taxes on harvests and investment to guide such a fishery along a dynamically optimal path.

Departing from the assumption that fisheries resources are under open access conditions, another branch of research has focused on the implications of various fisheries management instruments where adequate access restrictions are only partially established and/or effective. Homans and Wilen (1997) consider the case where the dynamics of a fishery is driven by rent dissipation under what they term "regulated open access," with regulations focused on the conservation of fish stocks changing in response to the adjustment of fishing fleets to the economic status of the fishery. Another management instrument that has received attention in fisheries is buyback programs. Buyback programs are directly aimed at reducing fishing capacity. The effects of buyback programs on investment behaviour were analysed by Weninger and McConnell (2000). The authors develop a Cournot model of investment and characterise investment equilibria for vessels operating in a total allowable catch (TAC) regulated fishery before and after the introduction of a buyback scheme. They conclude that while buyback programs reduce capacity in the shortrun, the fishermen remaining in the fishery have strengthened incentives to invest after the buyback, and the long-run capacity effects are therefore limited. These perverse impacts of buyback programs are also discussed by Holland, Gudmundsson, and Gates (1999).

In addition, Clark, Munro, and Sumaila $(2005,2007)$ show that buyback schemes can create a time consistency problem if vessel owners anticipate the schemes. The authors analyse this time consistency problem in a theoretical model based on Clark, Clarke, and Munro (1979). They find that under rational expectations regarding the policy of the fishery manager, the anticipated buybacks have the same effect as an immediate subsidy to vessel owners. The time consistency problem persists even if buybacks are combined with the introduction of access regulations in the form of an individual transferable quota (ITQ) system.

The impacts of introducing access regulations in fisheries have also attracted growing interest. Townsend (1985) discusses the implications of access regulations in fisheries. He 
the implications of the assumption that Welsch, and Kropp in an open-access ing costs. They use ities is unavoidable ntinues to grow for ion in fish biomass. artial substitutabilh they assume. can be difficult, as imaila (1995) modry game under the ssted by two fleets. , and in the second $\because$ Nash equilibrium the stock far below lution.

ro (1979) to allow 1or uses his model ion of irreversible eturns when make socially optimal excessive capital ck levels, low harential for taxes on timal path.

open access con$f$ various fisheries artially established : the dynamics of ted open access," in response to the ther management 3uyback programs ograms on investauthors develop a vessels operating introduction of a acity in the shortto invest after the srverse impacts of es (1999)

Jack schemes can mes. The authors in Clark, Clarke, the policy of the amediate subsidy :ks are combined ransferable quota

ittracted growing is in fisheries. He argues that fisheries managed by limited entry often experience increased use of capital by each firm, which counteracts the intention of limiting fishing effort. Townsend identifies six different incentives that cause increased use of capital in access regulated fisheries, but notes that not all incentives are economically undesirable. Hence, the net effect of introducing access regulations is uncertain. The incentives he identifies are: $i$ ) the output effect arising when limited entry increases marginal revenue per unit of effort, which, in turn, gives the individual firm incentives to increase output; $i$ i) the substitution effect arising when firms increase the use of unrestricted inputs while limiting the use of restricted inputs; $i i i$ ) the cost of capital goes down because of increased stability and higher revenues; $i v)$ the incentives to innovate increase since fewer vessels share the gains; $v$ ) the cross-substitution effect arising if firms no longer regard the marginal cost of the fish stock as zero, as may be the case under open access; vi) the consumption effect that arises if capital enters the individual utility function of fishermen. While the first two effects lead to reduced efficiency in production, the opposite is the case for the four remaining incentives.

Of particular interest to this review are the studies which focus on the influence of fishing rights on investment patterns in a fishery, particularly in the form of ITQs (Arnason 1990; Boyce 1992; Copes 1986; Grafton 1996). This management instrument has received widespread attention among economists, as the theoretical work on the implications of introducing ITQs suggests greater efficiency than with the command and control management approaches currently used in many fisheries. With command and control, efficiency is typically defined in terms of total economic value realised in the fishery over time.

In practice, where individual harvesting rights exist and are tradable between firms (ITQs), the harvesting rights can be considered a distinct type of capital in which investment is required for a firm to operate. Weninger and Just (2002) study entry and exit in a natural resource industry in which firms must invest in an output permit to enter the industry. Thus, in order to produce, firms must invest both in physical capital and output permits. The effects of uncertainty in the permit price, particularly in terms of entry and exit behaviour, are explored. Although not specifically focused on the fishing industry, their analysis also offers useful insights for fisheries. Hannesson (1996) investigates the long-run equilibrium levels of physical capital, quota holdings, and quota price in an ITQ regulated fishery with stochastic stock growth. The author finds that higher output price or lower interest rate causes the long-run equilibrium quota price to increase, which, in turn, may reduce each firm's optimal number of quota shares to hold.

In a later study, Hannesson (2000) analyses optimal investment under an ITQ system when the share system of remuneration is used. He finds that the share system can result in under or over investment under ITQs, depending on the catch share of the vessel owner. The incentive to invest is distorted for the vessel owner because the gain from obtaining an additional quota must be shared with the crew. Vessel owners would, therefore, be willing to pay less for quotas, which makes the alternative of investing in a new boat relatively more attractive.

Novak, Kaitala, and Feichtinger (1995) consider a case where a firm leases out the right to manage a fish resource from the government that entails payment of a resource fee reflecting the social value of the resource including both use and non-use values. Assuming perfectly malleable capital and increasing marginal costs of investment, the authors show that optimal investment policy for the firm is not necessarily towards a constant steadystate level, but rather periodic capital investments, which cause cycles in the fish stock. This is because the leasing firm must deal with two contradicting objectives of maximizing profits derived from extraction of the fish resource while seeking to maintain its biomass.

While these are potentially important implications of rights-based fisheries management for the capital dynamics of marine fisheries, it appears that few theoretical studies to date have explicitly analysed investment in the different components of capital in fisheries, including immaterial capital in the form of fishing rights. 


\section{Empirical Research}

Despite this substantial body of theoretical work, there are currently few empirical studies that primarily investigate investment in fisheries and the firm-level investment drivers in fisheries. A possible explanation is limited data availability on investment and capital in marine fisheries (Kirkley and Squires 1988). To estimate the theoretical models of firm-level investment presented in the review of theoretical studies, data on a range of economic variables by firm and over time are required. In particular, empirical studies in this domain depend on reliable estimates of capital stocks and their development; i.e., investments. Another possible explanation is the ongoing discussions on measurement of capacity (Kirkley, Morrison Paul, and Squires 2002). There are, however, some studies primarily focused on investment and relevant studies on related topics. Most focus on the behaviour of fishing operators and can be directly related to the second group of theoretical studies reviewed in the previous section. In the following, key results from these studies are summarised and commented upon. We first consider studies of entry-exit, which assume fishing operators can freely adjust their levels of capital and harvesting effort under open-access conditions. We then consider analyses of the effects of government interventions on capital dynamics in fisheries, including subsidies, buyback schemes, and access regulations. Finally, we examine research developments that have sought to identify the behavioural drivers of investment strategies at the level of individual fishers or fishing firms.

\section{Empirical Models of Entry-exit in Marine Fisheries}

Attempts at developing empirical models for entry-exit in particular fisheries have been limited. Early work in this area centred on the estimation of parameters measuring the speed at which fleets respond to changes in the average profitability of fisheries in terms of vessel entries and exits (Wilen 1976; Bjørndal and Conrad 1987). Wilen (1976) studied the dynamics of the North Pacific fur seal fishery from 1882 to 1899 . He developed a model that describes the cycles of an open-access fishery in terms of stock dynamics, harvesting, and profits in order to assess the likelihood of extinction if the fishery had remained open-access.

Following a similar approach, Bjørndal and Conrad (1987) conduct an empirical analysis of capital dynamics in the Norwegian North Sea herring fishery. They use data on purse seine vessels between 1963 and 1977 and measure effort in terms of standardized purse seine units. They assume that fleet adjustments are proportional to profits in the fishery. Bjørndal and Conrad (1987) allow for new vessels being built adding to the total number of boats when profits in the fishery are positive. Due to the time required to build new vessels, lagged values of average profits per boat are included as explanatory variables when estimating the fleet dynamics function. They find that the appropriate number of lags is two years, reflecting the time required to build a new purse seine vessel. Furthermore, Bjørndal and Conrad include the relative price of mackerel as an indicator of alternative fishing options and conclude that fleet adjustments depend on profits and returns in alternative fisheries.

Another study of entry-exit and investment drivers in marine fisheries is the Clark and Lamberson (1982) study of the pelagic whaling industry in Antarctica. This industry followed a boom and bust trajectory from 1925-1965, a development initiated by remarkably high profits during the early 1920s (Clark and Lamberson 1982). From 1946, a quota system was adopted by the International Whaling Commission, but since quotas were not allocated to countries or individuals, a race for catch was initiated and investments in capacity rose dramatically. Although excess capacity in the whaling fleet was largely due to this open access situation, Clark and Lamberson (1982) also stress that excess capacity

$c c$ 
w empirical studnvestment drivers tment and capital retical models of ata on a range of empirical studies development; i.e., a measurement of ver, some studies Most focus on the id group of theoesults from these lies of entry-exit, ind harvesting efzts of government ack schemes, and re sought to idenlividual fishers or

sheries have been ars measuring the fisheries in terms filen (1976) stud99. He developed f stock dynamics, he fishery had re-

luct an empirical ry. They use data erms of standardional to profits in uilt adding to the the time required luded as explanaat the appropriate urse seine vessel. el as an indicator nd on profits and

eries is the Clark ica. This industry itiated by remarkom 1946, a quota ince quotas were nd investments in it was largely due at excess capacity could also have occurred under a harvesting strategy driven by profit maximization. The economic interest of resource users in stock preservation would have been limited and depletion optimal from their point of view, given that the return on alternative investments surpassed annual sustainable yields from whaling. This emphasises the importance of the opportunity cost of capital when analysing investment and capacity adjustment strategies.

Kronbak (2005) investigates the dynamics of the Baltic Sea cod fishery, which is shared between the countries surrounding the Baltic Sea (Denmark, Finland, Germany, Sweden, Estonia, Latvia, Lithuania, Poland, and the Russian Federation). She calibrates the empirical model based on data of typical Danish vessels operating in the fishery, using data up until 1999 to estimate the biological part of the model. Similar to Bjørndal and Conrad (1987), the dynamics of fishing effort follow normalised profit, defined as a period's profit divided by output price times effort. Kronbak uses the model to study open access dynamics, including the stability of steady state. The results show that open access may lead to stock depletion. Nøstbakken (2008) carries out a similar analysis of the North Sea herring fishery between 1981 and 2001, but takes into account uncertainty in stock growth and focuses on optimal management.

Pascoe and Revill (2004) analyse entry and exit in the European brown shrimp fishery. The fishery is characterised by mobile effort that can easily be moved into and out of the fishery. The authors develop and calibrate a bioeconomic model using country level data to investigate the effects of an introduction of selective trawls to reduce bycatches. The gear restriction was legislated by the European Union and implemented in 2003. Pascoe and Revill start out by estimating the opportunity cost of operating in the fishery by country as the shadow price of each country's effort constraint, which is given by the observed effort level in 1997. Next, they relax the effort constraints and modify the catchability coefficients to account for the introduced gear restrictions. They assume that effort is only allocated to the fishery if the returns from fishing exceed the opportunity cost. The results show that the gear restriction increases efficiency, since it corrects the bycatch externality. However, the benefits are not equally shared between the different countries; some will gain while others will lose.

The first studies, presented above, measured capital as the number of boats that were assumed to be identical. This is a weakness, since both capital value and opportunity costs are likely to vary considerably between vessels and over time. This is confirmed by the study of Pascoe and Revill (2004), which looks at differences in opportunity costs across countries. More recent empirical studies have used a discrete choice modelling framework; particularly random utility modelling (RUM) to analyse behaviour at the individual fishing firm level, taking heterogeneity into account. In random utility models, agents make choices between different discrete alternatives based on what yields the highest utility. Agents' utility typically consists of a systematic component that is common to all agents and a random component that varies across agents. While these studies do not analyse investment per se, they seek to predict how existing and new vessels move into, out of, or between fisheries.

This work was initiated by Bockstael and Opaluch $(1983,1984)$, who investigate the transfer of vessels from one fishery to another. The authors consider three distinct decisions that fishermen can make: fishermen currently in a fishery can change their level of fishing activity, fishermen can switch between fisheries, and effort can change due to entry or exit from fishing. Bockstael and Opaluch argue that each of these decisions must be treated separately, since they are likely to depend on different factors. They develop a model of fishery alternative choices and apply this to the New England fisheries. They find that although fishermen respond to economic incentives, a large change in returns is required for fishermen to switch fisheries.

Ward and Sutinen (1994) develop a model of entry and exit, which they incorporate into a dynamic bioeconomic model of the Gulf of Mexico shrimp fishery. They model firms (vessels) that make decisions based on the expected profits associated with different 
discrete alternatives. Fishing firms can enter the fishery from an alternative fishery, construct a new vessel and enter from outside the fishing industry, remain in the fishery, exit the fishery to enter another fishery, or retire from the fishing industry. Ward and Sutinen used a multinomial logit specification that they estimated based on a random sample of about 300 vessels from 1965 to 1975 and 1981 to 1983 . Their results support that changes in effort are proportional to profits, as suggested by the theoretical work presented earlier. Furthermore, the results show that firms are more likely to enter the fishery when profits increase than they are to leave the fishery when profits decline. This is in line with the theoretical results for non-malleability or quasi-malleable capital discussed earlier (Clark, Clarke, and Munro 1979). In a similar study of Hawaiian long-liners, Pradhan and Leung (2004) used revenue by gross tonnage in a multinomial logit framework to consider exit and entry strategies versus staying in the fishery.

Table 1 summarises the estimation of entry and exit in the studies of individual fisheries surveyed above. Notice that only Ward and Sutinen (1994) make use of both cross-sectional and time-series data. All other studies use either cross-sectional data or time-series data. Recall that theoretical work on entry-exit predicts that entry and exit depend on profits in the industry. Of the studies listed in table 1, only Pradhan and Leung (2004) do not include a measure of profits in the estimated equation. Other explanatory variables used in the models include input and output prices (Bjørndal and Conrad 1987; Ward and Sutinen 1994), fish stock sizes (Bjørndal and Conrad 1987; Pradhan and Leung 2004; Ward and Sutinen 1994), and vessel and fleet characteristics (Pradhan and Leung 2004; Ward and Sutinen 1994). Bockstael and Opaluch $(1983,1984)$ use expected returns and the variability of returns as explanatory variables.

Table 1

Estimation of Investment Relationships: Selected Entry-exit Models

\begin{tabular}{llllll}
\hline Study & Aggregation & Observations & Estimator & Dependent Variable \\
\hline Bjørndal and Conrad (1987) & Fleet & 15 years & OLS & No. of vessels \\
Wilen (1976) & Fleet & 18 years & OLS & No. of vessels \\
Bockstael and Opaluch (1983) & Vessel & 657 vessels & Logit & $\begin{array}{l}\text { Fishery alternatives } \\
\text { (location and gear) }\end{array}$ \\
Bockstael and Opaluch (1984) & Vessel & 657 vessels & Logit & $\begin{array}{l}\text { Fishery alternatives } \\
\text { (location and gear) }\end{array}$ \\
Pradhan and Leung (2004) & Vessel & 347 vessels & Logit & $\begin{array}{l}\text { Fishery entry, stay, exit } \\
\text { choices }\end{array}$ \\
& & & Logit & $\begin{array}{l}\text { Fishery entry, stay, exit, } \\
\text { retire choices }\end{array}$ \\
\hline
\end{tabular}

\section{Government Interventions and Investment in Fisheries}

With an increase in the number of regulations that have been applied to marine fisheries, the cases where fisheries remain under free and open access have become increasingly rare. Hence, studies of investment behaviour have progressively extended to include the influence of regulations and the incentives they create. Here, we review a selection of recent studies that illustrate the key aspects dealt with in these studies. 
native fishery, con1 in the fishery, exit : Ward and Sutinen random sample of upport that changes tk presented earlier. ishery when profits ; is in line with the Issed earlier (Clark, Pradhan and Leung ork to consider exit

Idies of individual make use of both is-sectional data or that entry and exit Pradhan and Leung Other explanatory I and Conrad 1987; Pradhan and Leung ?radhan and Leung se expected returns

\section{: Models}

jendent Variable

of vessels

of vessels

tery alternatives ation and gear)

tery alternatives ation and gear)

lery entry, stay, exit ices

lery entry, stay, exit, e choices

o marine fisheries, come increasingly ided to include the $v$ a selection of re-

\section{Subsidies and Buyback Programs}

A recent OECD report deals with the implications of financial support to fisheries (OECD 2006). Among the different types of financial support considered are vessel decommissioning and licence retirement schemes and investment and modernisation subsidies. These issues directly affect fishery investment decisions. Other types of subsidies discussed in the report are relevant, as they may impact investment behaviour in fisheries indirectly (see also the report by Milazzo (1998) on fisheries subsidies).

With the need to reduce fishing capacity in overcapitalized fisheries, an increasing number of regulatory schemes offer payments to vessel owners to decommission their fishing unit as part of programmes designed to rationalise fishing fleets. The nature and impacts of these schemes are the focus of a recent book edited by Curtis and Squires (2007). Buyback programs are typically aimed at buying fishing licences and/or fishing vessels in order to reduce the fishing capacity of the fleet. The existence of such programs is assumed to affect the decision to exit, as it alleviates the capital non-malleability problem. However, as indicated in the previous section, it may also affect the decision to enter, as the existence of decommissioning programs and the anticipation of such programs in the future reduces the cost of capital by ensuring a higher minimum scrap value upon exit (Clark, Munro, and Sumaila 2005).

Guyader, Daurès, and Fifas (2004) develop and calibrate a bioeconomic simulation model of a French coastal fishery: the Saint Brieuc scallop fishery. The model is used to carry out a cost-benefit analysis of a decommissioning scheme. Their results show that the decommissioning scheme can reduce the number of vessels, but increased technical efficiency for vessels that remain in the fishery will counteract this. The authors argue that an allocation of fishing rights must be done with decommissioning schemes to avoid an increase in fishing effort from remaining vessels. This is in line with the theoretical work on buybacks presented above.

Mardle et al. (2006) compare models of entry, stay, and exit of vessels in three European fisheries using multinomial (unordered) logit models. The case studies considered are the Basque trawl fleet operating in the Bay of Biscay, a French trawler fleet of Southern Brittany, and the English beam trawl fleet operating in the North Sea. Results show that participation of vessels in a fishery are influenced by the age of vessels, expected revenues, and anticipated status of the fish stocks, and also by the decommissioning premiums that were paid by governments to buyback fishing capacity under the European buyback schemes.

The role of the US federal government in fishery investment decisions was examined by a task force that submitted their final report in 1999 (Report to Congress 1999). The study was a result of the Sustainable Fisheries Act enacted by Congress in 1996. The task force made efforts to identify and classify different types of subsidies potentially leading to increased investments. The following main categories were defined and analysed in the report: direct government payments, implicit payments or charges, price support programs, general programs that affect fisheries, and tax policies. Kirkley and Squires (1988) developed procedures for estimating capital stock and net investment using limited information on vessels, such as tonnage, length, and engine horsepower using the hedonic approach to estimate physical capital stock, which can then be used to estimate net investment. The authors show that investment in the New England commercial fishing fleet increased over their period of study (1965-1981), particularly following the adoption of the Magnuson Fisheries Conservation and Management Act of 1976. According to the authors, this could be linked to the adoption of the Act itself, or to the positive expectations regarding resource or economic conditions.

The effects of tax and depreciation legislation on investments in fisheries are addressed by Jensen (1998). The purpose of his study was to empirically analyse the investment behaviour of the Danish fishing fleet and how it was affected by tax con- 
siderations. The analysis was carried out through econometric estimation of investment behaviour based on aggregate data of the Danish fleet over the period 1960-1987. The use of aggregated data is in contrast to most empirical studies of investments in fisheries that typically employ data on individual units (vessels).

Jensen (1998) used the insurance value of the vessels to measure investment. Due to high tax rates and the possibility of vessel depreciation during construction, strong incentives for rapid investment in Danish fisheries were expected in years with relatively high profits, since firms could reduce their tax payments by ordering a new vessel. Jensen made the assumption that fishermen maximise profits and are price takers in input and output markets. According to theory, the desired level of capital depends on the production level (catches) and the user cost of capital. An increase in catches has a positive effect on capital stock, whereas the relationship between the user cost of capital and the desired capital level is negative.

Jensen finds that profits and user cost of capital, tax, and depreciation policies are statistically significant variables when explaining investment. This supports the theory of firms carefully considering tax levels and depreciation in their investments decisions. Long-term changes in the quantity of landings, on the contrary, have no significant effect on investment. Jensen concludes that the firms' investment behaviour appears economically rational, which suggests the possibility of taxing use of capital in order to influence investments. The results support observations of how relatively high tax rates and the opportunity of taxing depreciation in advance provide incentives to invest on the basis of tax system considerations rather than long-run profitability in the fishery, which is a dimension not explicitly captured in most of the theoretical studies reviewed in the previous section (Jensen 1998).

Le Floc'h et al. (2011) examine the influence of fiscal regulations on investment in French fishing fleets operating along the Atlantic coast. Using an unbalanced panel data set containing information on the investment decisions of a sample of fishing firms over the period 1994-2004, the authors assess key drivers that may have led these firms to invest or disinvest, including both economic variables and other factors, such as the career phases of skipper-owners. A key result of their analysis is that investment strategies were driven partially by the fiscal regime related to the profits of these firms and to the sale of vessels when fishers retired. The regime actually encouraged vessel owners to invest late in their career to reduce their levels of net profits, and hence, pay less tax when they sold their vessels upon retiring.

\section{Access Regulations}

Currently, most commercial fisheries are managed under some form of restricted access to fish resources. As discussed in the previous section, such restrictions are expected to affect the incentives to invest in capital in such fisheries (Townsend 1985). In addition, they may lead to the need to consider a category of capital, which we have referred to as immaterial capital and is required for the prosecution of a fishery (access rights). Here, we review some of the key lines of enquiry that have been pursued in the limited number of empirical studies of capital dynamics in access regulated fisheries.

The main implications of introducing fishing rights are the introduction of a cost of investment in fishing rights and a reduction in the race for fish. This creates incentives for less efficient firms to disinvest in fisheries where there is excess capacity, and all the more when alternative income possibilities exist.

Squires, Alauddin, and Kirkley (1994) conduct an ex ante analysis of the introduction of an ITQ program in the Californian sablefish fishery. A linear programming model is used in which quota and trade in quota affect the implicit marginal valuation of a firm's capital stocks. This, in turn, affects investment incentives. Capacity utilisation (CU)

meast

actual conce not tal use fo and $m$ (Squir

mise tl in the sible a ITQs v these $v$

mid-A period from i sel siz vessels ments introdu the fist vessels since th from I] conclu vertica ence in system ment it loans, of Icel Clarke being $\mathrm{f}$ able pr

Norwe disting theoret velops estimat 2001-2 investr investn cally e efficier least $n$ 
ation of investment dd 1960-1987. The stments in fisheries

re investment. Due onstruction, strong ears with relatively new vessel. Jensen takers in input and nds on the produc'hes has a positive $t$ of capital and the

ciation policies are iupports the theory estments decisions. to significant effect r appears economi1 order to influence 1 tax rates and the invest on the basis fishery, which is a iewed in the previ-

is on investment in alanced panel data f fishing firms over $d$ these firms to in, such as the career lent strategies were $s$ and to the sale of Nners to invest late tax when they sold

of restricted access ins are expected to 1985). In addition, have referred to as :cess rights). Here, the limited number

uction of a cost of sates incentives for $y$, and all the more

is of the introducogramming model aluation of a firm's y utilisation (CU) measures are presented as indicators of the incentives to invest or disinvest, although actual investment policies can differ. Using CU measures, however, suggests a possible concentration of quotas with some vessel owners or processors, but disinvestment may not take place instantly. Reasons for the delayed disinvestment include limited alternative use for the vessels, differences between discount rates experienced by the vessel owner and market discount rates, transaction and information costs, and initial quota distribution (Squires, Alauddin, and Kirkley 1994).

Campbell, Brown, and Battaglene (1999) studied the impacts of the introduction of ITQs in the Australian Southern bluefin tuna fishery. They do not estimate a model, but base their analysis on comparisons of summary statistics of vessels. They find that when ITQs were introduced, fleet adjustment occurred rapidly, and investments were directed to maximise the net value of the fishery. After the introduction of ITQs, considerable disinvestments in the Southern bluefin tuna fishery took place, which were made possible by easily accessible alternative fishing opportunities. Vessels that left the fishery upon the introduction of ITQs were typically also active in other fisheries. Since other fishing alternatives existed for these vessels, barriers to exit for this particular fishery were relatively small.

Brandt (2007) studied fleet restructuring following the introduction of ITQs in the US mid-Atlantic surf-clam fishery. She used data on vessels harvesting surf clams over the period 1983-1999 and estimates a model that distinguishes between improved efficiency from industry structure and improved vessel efficiency. Brandt uses information on vessel size and vertical integration with processing sector and horizontal integration across vessels and estimates efficiency gains of introducing ITQ for each of these vessel segments using a stochastic production frontier approach. Brandt observes that prior to the introduction of tradable property rights in the fishery, a number of vessels that had exited the fishery re-entered to establish claims to the initial quota allocation. These inefficient vessels made efficiency artificially low in the years prior to the introduction of ITQs, and since they exited the fishery once the quotas were allocated, they made the efficiency gain from ITQs look larger than it actually was. Brandt is able to correct for this distortion and concludes that efficiency gains for smaller vessels exceeded those of larger vessels, while vertically integrated firms gained more than other firms. She found no statistical difference in efficiency gains between independent and horizontally integrated firms.

Securing fishing rights may also entail new investment in fisheries. Eythórsson (1996) looked at the economic and social effects of introducing ITQ management in Iceland, including the effects on investments. He finds that the introduction of an ITQ system in Iceland represented a boost of new capital into the fishery encouraging investment in fleets. This was mainly due to the possibility of using quotas as security for bank loans, often for investments in modern freezer trawlers or fisheries enterprises outside of Iceland. This finding can be related to the non-malleability issue dealt with by Clark, Clarke, and Munro (1979) discussed in the previous section. With physical capital not being perfectly malleable, such assets are not as valuable securities for bank loans as tradable production quotas.

In a recent study, Nøstbakken (2011) analyses firm-level investment behaviour in the Norwegian purse seine fishery, which is managed by transferrable quotas. The analysis distinguishes between investment in physical capital and quota capital, in line with the theoretical work of Hannesson (1996) and Weninger and Just (2002). Nøstbakken develops a theoretical model of firm-level investment in quota and production capital and estimates a reduced form of the model using data on Norwegian purse seine firms from 2001-2005. The main result is that while the basic economic investment model explains investment behaviour within firms over time well, it does not explain differences in investment between firms. Hence, it is not necessarily the case that the most economically efficient firms invest, while less efficient firms disinvest in an ITQ fishery. Thus, the efficiency gain from introducing tradable quotas predicted by theory may not occur, at least not in the short run. Nøstbakken introduces additional firm-specific variables to the 
empirical model in an attempt to better explain differences in investment behaviour between firms. Her analysis shows that investment depends on how much the firms initially paid for their quotas. This suggests that firms do not necessarily take into account the full opportunity cost of quotas when making decisions if they obtain quotas at prices below market value. In addition, the geographical location of the firm, the number of owners, and whether the firm is family operated affects firm-level investment behaviour.

When access to fisheries is limited by regulation, access rights become valuable and represent a new form of capital for investment purposes. Flaaten, Heen, and Salvanes (1995) analyse capitalisation of resource rent in a limited-access fishery. Their hypothesis is that the profitability of a vessel that obtained its license for free is higher than that of a vessel with a purchased license. To assess this hypothesis, tests of differences in the profitability between the two groups of vessels are conducted. Flaaten, Heen, and Salvanes conclude that the difference between groups in gross profit margin (defined as income from fishing minus share to crew and operating profits) is not significant. Both depreciation and interest payments are, however, found to be significantly higher for vessels with a purchased license, implying a higher user cost of capital. Finally, a test for differences in net return on investment reveals significant differences between the two groups of vessels. Hence, the main hypothesis is not rejected; there is a significant difference in profitability of the two vessel groups. This emphasises the importance of distinguishing between investment in physical capital (vessels and gear) and in immaterial capital relating to fishing access rights (transferable licenses or quotas).

Guyader et al. (2003) apply the hedonic modelling approach proposed by Kirkley and Squires (1988) to the estimation of intangible assets in French fleets operating in the Northeast Atlantic. The authors test the hypothesis that the price of vessels traded on the second-hand market can be separated into two components: a tangible value explained by technical characteristics and age of the fishing units, and an intangible value representing the price of access rights to the fisheries. These harvesting rights may, to some extent, capitalise the value of the rent or quasi-rent flows derived from fishing. ${ }^{1}$ The results confirm the assumption that vessel prices do not only reflect the value of tangible capital, but also include the price of intangible capital. While vessel size and age significantly influence vessel prices, operation permits and licenses account for a large proportion of vessel prices on the second-hand market. The authors find that this share increases with vessel age and depreciation of tangible capital due to wear and tear.

A related study is Daurès et al. (2006) who measured the value of net capital stock for the French fishing fleets using the hedonic approach. Based on a time series of acquisition prices of new vessels, regression models were tested to measure gross capital stock at a given time and estimate a depreciation function of vessel price as a function of vessel age. The gross capital stock (or acquisition price) was estimated by the model, and the net capital stock was calculated after the use of a depreciation function. This estimated net capital stock value can be different from the market value of the vessel, which encompasses the implicit value of intangible assets, specifically fishing rights in the French context where explicitly tradable individual access rights do not exist (Guyader, Berthou, and Daurès 2007).

Although different methodologies were used in the different studies reviewed above, results point to the fact that when analysing investment in access regulated fisheries, we must take into account the various fishing rights that apply, in addition to physical assets, such as vessels and fishing gear. Consequently, we must also take into account the possible effects on immaterial capital when evaluating regulations and policies aimed at limiting the use of physical capital.

Table 2 gives an overview of the estimations carried out in selected studies, presented above, that are based on a modelling approach. Note that Squires, Alauddin, and Kirkley

${ }^{1}$ Quasi-rent is a short-term concept and represents the return earned on a sunk-cost investment in excess of post-investment opportunity costs. 
nent behaviour be$\mathrm{h}$ the firms initially ato account the full tas at prices below number of owners, shaviour.

come valuable and [een, and Salvanes y. Their hypothesis igher than that of a rences in the profIeen, and Salvanes defined as income ant. Both depreciaier for vessels with test for differences the two groups of icant difference in e of distinguishing iterial capital relat-

oposed by Kirkley ts operating in the ssels traded on the value explained by value representing ty, to some extent, 1 The results conangible capital, but significantly influroportion of vessel ;reases with vessel

ıet capital stock for eries of acquisition ; capital stock at a tion of vessel age. , and the net capital ed net capital stock Ipasses the implicit xt where explicitly rès 2007).

:s reviewed above, lated fisheries, we on to physical ase into account the I policies aimed at studies, presented Iddin, and Kirkley
(1994) use a linear programming approach, so the estimated quota price equation is just part of their investment analysis. However, the information on the data used in the study applies to the full analysis, not just the estimation of a quota price function. Table 2 shows that only two studies make use of panel data methods when estimating their models (Flaaten, Heen, and Salvanes 1995; Nøstbakken 2011). Given that investment decisions are dynamic in nature, as they determine flows that affect capital stock variables and they are made at the firm or vessel owner level, it is surprising that not more empirical work is done using panel models of investment.

Looking at explanatory variables included in the studies listed in table 2, we find that only two include input or output prices (Nøstbakken 2011; Squires, Alauddin, and Kirkley 1994). However, Nøstbakken (2011) constructs her input prices based on data on input use and production levels. All but one study include measures of one or more capital stocks (fish stock, physical capital, quota capital). However, as measures of physical capital Brandt (2007) uses vessel length, Jensen (1998) uses the insurance value of fishing vessels, while Nøstbakken (2011) uses the Norwegian Directorate of Fisheries' estimates of the capital value of vessels, which are based on the replacement costs of the different components of the vessel. If we look at input prices, only two studies use these in estimations (Nøstbakken 2011; Squires, Alauddin, and Kirkley 1994). In general, it appears that the economic variables typically used in the theoretical models of investment (be these under assumptions of sole ownership or multiple firms) are not available for many fisheries. Hence, it is not straightforward to estimate the relationships proposed by the theoretical literature.

Table 2

Estimation of Investment Relationships: Government Policies

\begin{tabular}{|c|c|c|c|c|c|}
\hline Study & Topic & Aggregation & Obs. & Estimator & Dependent Variable \\
\hline Brandt (2007) & $\begin{array}{l}\text { Efficiency gain } \\
\text { from ITQs }\end{array}$ & Vessel & $\begin{array}{l}1,248 \text { vessel- } \\
\text { year obs. }\end{array}$ & Logit & Harvest \\
\hline $\begin{array}{l}\text { Flaaten, Heen, } \\
\text { \& Salvanes (1995) }\end{array}$ & $\begin{array}{l}\text { Limited entry \& } \\
\text { resource rents }\end{array}$ & \& Vessel & $\begin{array}{l}48 \text { vessels, } \\
2 \text { years }\end{array}$ & $\begin{array}{l}\text { OLS \& } \\
\text { random } \\
\text { effects }\end{array}$ & $\begin{array}{l}\text { 1) Gross revenue } \\
\text { 2) Operating costs }\end{array}$ \\
\hline Jensen (1998) & $\begin{array}{l}\text { Investment } \\
\text { drivers }\end{array}$ & Vessel & 28 years & OLS & Vessel investments \\
\hline Nøstbakken (2011) & $\begin{array}{l}\text { Investment } \\
\text { drivers ITQ }\end{array}$ & Owners & $\begin{array}{l}195 \text { owner- } \\
\text { year obs. }\end{array}$ & $\begin{array}{l}\text { Random } \\
\text { effects, fixed } \\
\text { effects }\end{array}$ & $\begin{array}{l}\text { 1) Physical capital } \\
\text { inv. } \\
\text { 2) Quota inv. }\end{array}$ \\
\hline $\begin{array}{l}\text { Squires, Alauddin, } \\
\text { \& Kirkley (1994) }\end{array}$ & $\begin{array}{l}\text { Efficiency gain } \\
\text { from ITQs }\end{array}$ & Vessel & 139 vessels & Tobit & Quota price \\
\hline
\end{tabular}

\section{The Role of Behavioural Drivers in Observed Investment Strategies}

Another strand of research has focused on the role of behavioural drivers in observed investment strategies. Traditionally, the solution to overexploitation and overcapitalization in fisheries proposed by economic theory has been to assign property rights to the resource in order to optimise management. There are, however, studies that suggest that despite having exclusive property rights, individuals tend to overinvest and mismanage 
the resource. Moxnes (1998) investigates whether the agents in the fisheries sector have the correct perception of the bioeconomics of their resource. His results suggest that there are tendencies to overinvest in capacity because individuals apply an investment rule that is rational for a flow resource but not optimal for stock resources, such as fisheries.

Moxnes used an experimental approach to the problem where the subjects were asked to manage a fictitious fishing firm over a 20 -year period. Three different groups of subjects were involved in the experiments: fishermen, bureaucrats, and researchers. The fish stock was said to be cod in an isolated fjord, and the subject has exclusive property rights of the stock. For every year, decisions had to be made to order new vessels and on the utilisation of existing vessels. Information on the economics of the fishing firm, catches, fish weight, and biomass estimates was available to the subject.

Important results from the experiment include the fact that the average fleet size controlled by subjects was $60 \%$ larger than economically optimal. Furthermore, most over-investments are conducted during the first year of management, indicating an "erroneous initial analysis" (Moxnes 1998). Lay up of vessels (reduced utilisation) is typically used when the adverse effects of overinvestment are revealed, and this is used relatively more in later periods. Additionally, capacity utilisation is strongly correlated with investment behaviour; the aggressive investors also utilise the fleet more aggressively.

The tendency to overinvest found by Moxnes (1998) can be explained by an information problem. Even though subjects are introduced to all relevant information, they might not fully perceive all relevant information and will consequently not act optimally due to the immediate complexity of the problem.

In addition to the general tendency to overinvest identified by Moxnes (1998), Christensen and Raakjær (2006) argue that fishing tactics and strategic decisions vary across fishermen. Using interviews and questionnaires they attempt to shed light on short- and longer-term decisions by analysing a cross-section of Danish commercial demersal fishermen. An example of short-term decisions is choice of fishing tactics, such as choosing fishing location and what gear to use, whereas longer-term decisions can be related to investment. One of the main findings regarding investment behaviour is that the age of the fishermen influences the level and type of investment. Younger fishermen invest more than fishermen approaching retirement, who typically only maintain their vessel(s). Christensen and Raakjær (2006) define three main types of fishermen. The first owns a small fishing vessel and often has no debt. Another is similar in the sense that (s)he is a careful investor, but differs in that (s)he operates a bigger vessel. The final group consists of fishermen characterised as dynamic investors making large investments typically in trawlers. However, it should be noted that the identification of types of fishermen depends on the fishery in question.

Another possibly important determinant of investment behaviour is the organisational structure of fishing firms. First, fisheries characterised by small owner-operated units may not respond to certain incentives in the same way as fishing firms that own large fishing vessels that require a large crew, since both the objective function and the possibilities of an owner-operator in a small-scale fishery may differ significantly from the objective function of a large fishing corporation. Hence, the organisation and scale of the fishery may affect investment behaviour. This is supported by the results of Nøstbakken (2011), who finds that family firms invest significantly more in the Norwegian purse seine industry than other firms. See also Brandt (2007), discussed above. Second, the possibility of vertical integration may have important implications for investment behaviour. Economic studies of fisheries typically assume that the harvesting sector is independent of the processing sector. However, if there is vertical integration, the investment problem changes. Several studies, including Clark and Munro (1980), have analysed implications of vertical integration for fisheries management policy, but little work has been done to analyse the implications of this on investment behaviour.

Pe

$\mathrm{Ou}$

ma:

tior

Tht

$\mathrm{Ma}$

cal

Fla:

phy

The

and

thes

as $s$

mer

whe

ecor

of th

capi

inve

othe

of $c$

inin

pers

the

on $t$

we

Fina

indu

Imp

Ano

on is

lem

with

pote

sequ

mer

affe

is al

grov

capi

on $f$

fishe 
leries sector have suggest that there vestment rule that s fisheries.

he subjects were ifferent groups of researchers. The xclusive property new vessels and the fishing firm,

Iverage fleet size urthermore, most licating an "erroation) is typically is used relatively lated with investssively.

sd by an informaation, they might optimally due to

es (1998), Chris;ions vary across sht on short- and al demersal fishsuch as choosing san be related to $s$ that the age of men invest more vessel(s). Chrisrst owns a small (s)he is a careful I consists of fishcally in trawlers. 1 depends on the he organisational erated units may wn large fishing the possibilities om the objective le of the fishery stbakken (2011), urse seine indushe possibility of viour. Economic ident of the proroblem changes. ations of vertical te to analyse the

\section{Perspectives for Future Work}

Our review of the theoretical fisheries economic literature shows that only some of the many aspects of investment and capital adjustment have been investigated. In this section, we provide some conclusions and propose topics for future research.

\section{Theoretical Models of Optimal Investment in Different Types of Capital}

Many studies, particularly theoretical studies, focus exclusively on investment in physical capital or in some aggregate measure of capital. As shown by Hannesson (1996) and Flaaten, Heen, and Salvanes (1995), it is important to distinguish between investment in physical capital and immaterial capital, such as transferable quotas or fishing licenses. There are, however, few studies of the different components of capital in marine fisheries and notably of investment in human capital and immaterial assets (fishing rights) where these exist. Human capital is rarely, if ever, mentioned in studies of investment, although as stressed by Munro (2010), it may pose issues similar to those encountered with investment in physical capital, particularly regarding its limited malleability. Furthermore, whereas there is a strong interest in ITQs and access-regulation instruments among economists, there is still limited empirical analysis of the relation between the operation of these schemes and the existence and evolution of investment strategies in immaterial capital. Overall, little work has been done on how fishing firms jointly determine their investment in physical, human, and immaterial capital on the policy effects of this and other related issues.

Extending the existing theoretical modelling framework to account for different types of capital represents an important avenue for future research. A first step involves examining the optimal level of physical, immaterial, and human capital from a social planner perspective, both at the aggregate and disaggregate levels. Next, there is a need to identify the optimal investment policy in this situation at the fishing firm level. This will depend on the regulatory framework. For example, if a firm operates in an ITQ regulated fishery, we must ask how much it should invest in physical capital, human capital, and quotas. Finally, theoretical work is needed to identify policy instruments and policy design that induces firms to act according to the objectives of the social planner.

\section{Implications of Uncertainty on Investment Behaviour}

Another issue that strikes us is that few studies focus on the implications of uncertainty on investment, capital, and capacity. This could be because of the complexity of the problem at hand even without stochastic elements in the models. Nonetheless, in an industry with natural variability playing such an important role as in fisheries, uncertainty may potentially have a great impact on the investment decisions of the fishing firms and, consequently, the capacity development of the fleet as a whole.

With the rapid increase in computational power and improvements in available numerical methods, there is great scope for increasing the knowledge of how uncertainty affects investment and capital adjustment in fisheries by use of numerical modelling. This is also an interesting topic for future empirical research. How does variability in stockgrowth, output prices, quota prices, etc., affect a firm's investment in different types of capital? What can the regulator do to alleviate potential negative impacts of uncertainty on firms? What are the implications of uncertainty for policy regarding management of fisheries and choice of policy instruments? 


\section{Econometric Studies of Investment}

Capital is closely related to fishing capacity; hence, changes in capacity also relate closely to changes in capital. But whereas there is a large empirical literature on measuring capacity and capacity utilisation in fisheries, far less work has been done on investment and drivers of investment in fisheries. Furthermore, the work that has been done has been predominantly theoretical.

Overall, less research has been done in which economic models of investment and capacity development have been empirically specified and estimated. One likely reason is the lack of detailed data on investment and other economic variables (Kirkley and Squires 1988). A common problem when using econometric methods to analyse investment behaviour is limited data availability. If the time series are not very long and the number of observations not very large, it is quite possible that standard econometric methods for analysing investment behaviour will not work well. Furthermore, complete econometric specifications of investment models typically require data on many variables with a relatively high level of detail. This also explains the popularity of data envelopment analysis (DEA) and other similar approaches in studies of capacity and capacity utilisation, as these methods are far less data intensive than many econometric methods. Several comprehensive reviews of the literature on capacity and capacity utilisation already exist, and we have not examined this part of the literature in our survey (see the review by Pascoe 2007).

The lack of reliable economic data combined with the considerable attention devoted to fishing capacity and its management call for setting up data collection procedures that ensure that time series suitable for comprehensive econometric analysis of investment behaviour become available. In addition, research should be devoted to developing better methods for valuating both physical and immaterial capital stocks based on available data. Finally, there is great potential for econometric analysis of firm-level investment behaviour. This involves identifying investment drivers and how such drivers are affected by the regulatory framework and other factors. One possibility is to develop and estimate structural models based on the theoretical framework discussed earlier. Eventually, the investment models developed could be integrated in coupled bio-economic simulation models to improve the ability of decision support tools to predict the medium- to longterm responses of fisheries to management strategies.

\section{Fishery Organisation and Investment Behaviour}

There has been little work, both theoretical and empirical, on how the organisation of the fishery (scale, vertical integration, type of owners) affects investment and capacity development. When analysing investment behaviour, it is important to identify the appropriate decision making unit. It is crucial to analyse investment and capacity adjustment decisions at the level where such decisions in fact take place. Traditionally, empirical analyses of investment and capacity adjustment in fisheries have been conducted at the vessel level. This is likely a result of how data have typically been collected, namely focusing on vessels. In many fisheries, it is not unusual that several vessels are controlled and operated by the same firm or owners. Hence, the appropriate level of analysis could be at the firm or owner level, not at the vessel level. In some artisanal fisheries, fishing may be carried out by households as part of a broader set of revenue-generating activities, and investment in the fishing component of the household business may be dependent on non-fishing related factors, such that the household may be the relevant decision unit to consider. In vertically integrated fishing firms, which include a catching and a processing activity, the drivers of investment in the catching activity may also be influenced by factors that relate to processing, and the firm level, including processing, may be the relevant decision unit. Hence, in a large number of cases, analysis of investment in fishing

will nee

identific

significa

appropri

vessel le

Res

invest? I

other fin

the effici

ing firms

answer t

The Imp

The num appears $\mathrm{r}$ ticularly fisheries, tions hav comprises Rese: of the pre one way a separate how inves involves identified investmer Does the efficiency

Anot on the re possibility in physica affect the relationsh represents

\section{Referenc}

Arnason, Econ Bjørndal, Mari

Bockstael Unce Mana 198 ics 1:

Botsford, lution 
ity also relate closerature on measuring done on investment i been done has been

s of investment and One likely reason is (Kirkley and Squires lyse investment beong and the number ometric methods for implete econometric ariables with a relanvelopment analysis y utilisation, as these Several comprehenready exist, and we sw by Pascoe 2007). le attention devoted tion procedures that lysis of investment 1 to developing bet; based on available m-level investment drivers are affected evelop and estimate lier. Eventually, the sonomic simulation e medium- to long-

the organisation of tment and capacity I identify the approsapacity adjustment itionally, empirical in conducted at the llected, namely fossels are controlled sl of analysis could al fisheries, fishing enerating activities, ay be dependent on ant decision unit to ling and a processoo be influenced by ng, may be the relvestment in fishing will need to be carried out at levels other than the vessel. This will also allow for easier identification of trade in second-hand vessels and fishing rights, which may account for a significant share of the overall investment decisions undertaken in a fishery. However, the appropriate specification depends on the characteristics of the fishery, and analysis at the vessel level may, in many cases, give an accurate representation.

Research questions related to this topic include: How do different types of owners invest? Do large firms differ from small firms? Do family firms invest differently from other firms? How does vertical integration affect investment and capital adjustment? Can the efficiency of the fishery be increased if we impose restrictions on who can own fishing firms or operate in the fishery? Both theoretical and empirical research is required to answer these and related questions.

\section{The Impacts of Public Policies on Investment}

The number of studies focusing on the impacts of public policies on investment strategies appears relatively limited, although such policies may have significant consequences, particularly when they relate to fishery access regulation. Furthermore, in many commercial fisheries, access rights, licences, quotas, and other instruments introduced through regulations have become objects of investment. Hence, the fishing firms' investment decision comprises investment in these capital assets in addition to physical capital.

Research on the relationship between public policies and investment is related to all of the previously mentioned research topics, since basically every fishery is regulated in one way or another. Given the importance of public policies, we present the topic under a separate heading. Both theoretical and empirical work is needed to better understand how investment behaviour is affected by policy and specific regulatory instruments. This involves the investment in physical capital as well as other types of capital. We have identified a particular need for more empirical work on this topic. What drives firm-level investment in physical capital and fishing rights in ITQ or access regulated fisheries? Does the introduction of ITQs in a fishery lead to reduced excess capacity and increased efficiency as predicted by theoretical models?

Another highly relevant issue is non-compliance and illegal fishing, which depends on the regulator's ability to enforce fishery regulations and quotas. A firm that has the possibility to exceed quotas and harvest fish illegally may have incentives to invest more in physical capital than a compliant firm. The possibility to fish illegally is likely to also affect the demand for immaterial and human capital. Little work has been done on the relationship between non-compliance and firm-level investment behaviour. Hence, this represents a promising and relevant topic for future research.

\section{References}

Arnason, R. 1990. Minimum Information Management in Fisheries. Canadian Journal of Economics 23:630-53.

Bjørndal, T., and J.M. Conrad. 1987. Capital Dynamics in the North Sea Herring Fishery. Marine Resource Economics 4:63-74.

Bockstael, N.E., and J.J. Opaluch. 1983. Discrete Modelling of Supply Response under Uncertainty: The Case of the Fishery. Journal of Environmental Economics and Management 10:125-37.

. 1984. Behavioral Modeling and Fisheries Management. Marine Resource Economics 1:105-15.

Botsford, L.W., and T.C. Wainwright. 1985. Optimal Fishery Policy: An Equilibrium Solution with Irreversible Investment. Journal of Mathematical Biology 21:317-27. 
Boyce, J.R. 1992. Individual Transferable Quotas and Production Externalities in a Fishery. Natural Resource Modeling 6:385-408.

1995. Optimal Capital Accumulation in a Fishery: A Nonlinear Irreversible Investment Model. Journal of Environmental Economics and Management 28:324-39.

Brandt, S. 2007. Evaluating Tradable Property Rights for Natural Resources: The Role of Strategic Entry and Exit. Journal of Economic Behavior \& Organization 63:158-76.

Burt, O.R., and R.G. Cummings. 1970. Production and Investment in Natural Resource Industries. American Economic Review 60:576-90.

Campbell, D., D. Brown, and T. Battaglene. 1999. Individual Transferable Catch Quotas: Australian Experience in the Southern Bluefin Tuna Fishery. Marine Policy 24:109-17.

Charles, A.T. 1983. Optimal Fleet Investment under Uncertainty. Canadian Journal of Fisheries and Aquatic Sciences 40:2080-91.

1985. Nonlinear Costs and Optimal Fleet Capacity in Deterministic and Stochastic Fisheries. Mathematical Biosciences 73:278-300.

2007. Linking Natural Capital and Physical Capital: A Review of Renewable Resource Investment Models. Essays in Fisheries Economics and Management: $A$ Festschrift in Honour of Gordon Munro, T. Bjørndal, D.V. Gordon, R. Arnason, and U.R. Sumaila, eds., ch. 8. Oxford: Blackwell.

Christensen, A.-S., and J. Raakjær. 2006. Fishermen's Tactical and Strategic Decisions-A Case Study of Danish Demersal Fisheries. Fisheries Research 81:258-67.

Clark, C.W. 1976. Mathematical Bioeconomics. New York: Wiley \& Sons.

Clark, C.W., F.H. Clarke, and G.R. Munro. 1979. The Optimal Exploitation of Renewable Resource Stocks: Problems of Irreversible Investment. Econometrica 47:25-47.

Clark, C.W., and R.H. Lamberson. 1982. An Economic History and Analysis of Pelagic Whaling. Marine Policy 6:103-20.

Clark, C.W., and G.R. Munro. 1975. The Economics of Fishing and Modern Capital Theory: A Simplified Approach. Journal of Environmental Economics and Management 2:92-106.

1980. Fisheries and the Processing Sector: Some Implications for Management Policy. The Bell Journal of Economics 11:603-16.

Clark, C.W., G.R. Munro, and U.R. Sumaila. 2005. Subsidies, Buybacks, and Sustainable Fisheries. Journal of Environmental Economics and Management 50:47-58. 2007. Buyback Subsidies, the Time Consistency Problem, and the ITQ Alternative. Land Economics 83:50-8.

Copes, P. 1986. A Critical Review of the Individual Quota as a Device in Fisheries Management. Land Economics 62:278-91.

Curtis, R., and D. Squires. 2007. Fisheries Buybacks. Ames, IA: Wiley-Blackwell.

Daurès, F., J. Bihel, O. Guyader, P. Le Floc'h, N. Roudaut, C. Brigaudeau, O. Thébaud, and M. Jézéquel. 2006. Estimating Capital Value and Depreciation of Fishing Fleets: Application to French Fisheries. Proceedings of the Thirteenth Biennial Conference of the International Institute of Fisheries Economics and Trade (IIFET), University of Portsmouth, UK.

Eisenack, K., H. Welsch, and J.P. Kropp. 2006. A Qualitative Dynamical Modelling Approach to Capital Accumulation in Unregulated Fisheries. Journal of Economic Dynamics and Control 30:2613-36.

Eythórsson, E. 1996. Theory and Practice of ITQs in Iceland-Privatization of Common Fishing Rights. Marine Policy 20:269-81.

Flaaten, O., K. Heen, and K.G. Salvanes. 1995. The Invisible Resource Rent in Limited Entry and Quota Managed Fisheries: The Case of Norwegian Purse Seine Fisheries. Marine Resource Economics 10:341-56.

Garcia, S.M., and R.J. Grainger. 2005. Gloom and Doom? The Future of Marine Capture Fisheries. Philosophical Transactions of the Royal Society B: Biological Sciences 360:21-46. 
alities in a Fish-

eversible Invest28:324-39. ces: The Role of 'ion 63:158-76. latural Resource e Catch Quotas: licy 24:109-17. dian Journal of $c$ and Stochastic of Renewable Management: $A$ R. Arnason, and

Strategic Decich 81:258-67.

in of Renewable $47: 25-47$.

tlysis of Pelagic

Modern Capital cs and Manageor Management and Sustainable $47-58$.

[TQ Alternative.

I Fisheries Man-

lackwell.

au, O. Thébaud, f Fishing Fleets: nial Conference ET), University

lical Modelling tal of Economic

ion of Common

Rent in Limited Seine Fisheries. Marine Capture 'ogical Sciences
Gordon, H.S. 1954. The Economic Theory of a Common Property Resource: the Fishery. Journal of Political Economy 62:124-42.

Grafton, R.Q. 1996. Individual Transferable Quotas: Theory and Practice. Reviews in Fish Biology and Fisheries 6:5-20.

Gréboval, D., and G. Munro. 1999. Overcapitalization and Excess Capacity in World Fisheries: Underlying Economics and Methods of Control. FAO Fisheries Technical Paper, Ch. 1, pp. 1-48. FAO: Rome.

Guyader, O., P. Berthou, and D. Daurès. 2007. Decommissioning Schemes and Capacity Adjustment: A Preliminary Analysis of the French Experience. Fisheries Buybacks, R. Curtis and D. Squires, eds., Ch. 7. Ames, IA: Wiley-Blackwell.

Guyader, O., F. Daurès, and S. Fifas. 2004. A Bioeconomic Analysis of the Impact of Decommissioning Programs: Application to a Limited-entry French Scallop Fishery. Marine Resource Economics 19:225-42.

Guyader, O., L. Le Pellec, E. Pons, and F. Daurès. 2003. Analysis of Vessel Prices on Second-hand Markets (Atlantic Area-France). Proceedings of the XVth Conference of the European Association of Fisheries Economists, Brest, France.

Hannesson, R. 1987. Optimal Catch Capacity and Fishing Effort in Deterministic and Stochastic Fishery Models. Fisheries Research 5:1-21. 1993. Bioeconomic Analysis of Fisheries. Oxford: Fishing News Books. 1996. Long-term Industrial Equilibrium in an ITQ Managed Fishery. Environmental and Resource Economics 8:63-74. 2000. A Note on ITQs and Optimal Investment. Journal of Environmental Economics and Management 40:181-8.

Holland, D., E. Gudmundsson, and J. Gates. 1999. Do Fishing Vessel Buyback Programs Work: A Survey of the Evidence. Marine Policy 23:47-9.

Homans F.R., and J.E. Wilen. 1997. A Model of Regulated Open Access Resource Use. Journal of Environmental Economics and Management 32:1-21.

Ikiara, M.M., and J.G. Odink. 1999. Fishermen Resistance to Exit Fisheries. Marine Resource Economics 14:199-214.

Jensen, C.L. 1998. Investment Behavior and Tax Policy. Marine Resource Economics 13:185-96.

Jørgensen, S., and P.M. Kort. 1997. Optimal Investment and Finance in Renewable Resource Harvesting. Journal of Economic Dynamics and Control 21:603-30.

Kennedy, J.O.S. 1989. Approximately Optimal Recovery of a Multicohort Fishery from Depleted Stocks and Excess Vessel Capacity. Journal of the Operational Research Society 40:231-41.

Kirkley, J., C.J. Morrison Paul, and D. Squires. 2002. Capacity and Capacity Utilization in Common-Pool Resource Industries. Environmental and Resource Economics 22:71-97.

Kirkley, J., and D. Squires. 1988. A Limited Information Approach for Determining Capital Stock and Investment in a Fishery. Fishery Bulletin 86:339-49.

Kronbak, L.G. 2005. The Dynamics of an Open-Access Fishery: Baltic Sea Cod. Marine Resource Economics 19:459-79.

Le Floc'h, P., F. Daurès, M. Nourry, O. Thébaud, M. Travers, S. Van Iseghem. 2011. The Influence of Fiscal Regulations on Investment in Marine Fisheries: A French Case Study. Fisheries Research 109:257-64.

Mackinson, S., U.R. Sumaila, and T.J. Pitcher. 1997. Bioeconomics and Catchability: Fish and Fishers Behaviour during Stock Collapse. Fisheries Research 31:11-17.

Mardle, S., O. Thébaud, O. Guyader, T. Hutton, R. Prellezo, M. Travers. 2006. Empirical Analysis of Fishing Fleet Dynamics: Entry, Stay and Exit Choices in Selected EU Fisheries. Proceedings of the Conference of the International Institute for Fisheries Economics and Trade, Portsmouth, UK: $17 \mathrm{p}$. 
McKelvey, R. 1985. Decentralized Regulation of a Common Property Renewable Resource Industry with Irreversible Investment. Journal of Environmental Economics and Management 12:287-307.

Milazzo, M. 1998. Subsidies in World Fisheries-A Reexamination. Technical paper no. 406. The World Bank, Washington, DC, USA.

Moxnes, E. 1998. Not Only the Tragedy of the Commons: Misperceptions of Bioeconomics. Management Science 44:1234-48.

Munro, G.R. 1998. The Economics of Overcapitalization and Fishery Resource Management: A Review. Overcapacity, Overcapitalization and Subsidies in European Fisheries: Proceedings of a Workshop. A. Hatcher and K. Robinson, eds. Portsmouth, UK: CEMARE.

2010. The Way Forward: Getting the Economic Theory Right-The First Steps. Proceedings of the Conference of the International Institute for Fisheries Economics and Trade, Montpellier, France, July, 23 p.

Novak, A., V. Kaitala, and G. Feichtinger. 1995. Resource Leasing and Optimal Periodic Capital Investments. Mathematical Methods of Operations Research 42:47-67.

Nøstbakken, L. 2008. Stochastic Modelling of the North Sea Herring Fishery under Alternative Management Regimes. Marine Resource Economics 23:65-86.

2011. Investment Drivers in a Fishery with Tradable Quotas. Land Economics, forthcoming.

OECD. 2006. Financial Support to Fisheries-Implications for Sustainable Development. Paris: Organisation for Economic Co-operation and Development.

Pascoe, S. 2007. Capacity Analysis and Fisheries Policy: Theory versus Practice. Marine Resources Economics 22:83-7.

Pascoe, S., and A. Revill. 2004. Costs and Benefits of Bycatch Reduction Devices in European Brown Shrimp Trawl Fisheries. Environmental and Resource Economics $27: 43-64$.

Pradhan, N.C., and P. Leung. 2004. Modeling Entry, Stay, and Exit Decisions of the Longline Fishers in Hawaii. Marine Policy 28:311-24.

Report to Congress. 1999. The Federal Fisheries Investment Task Force. Available online at: <http://www.nmfs.noaa.gov/sfa/ITF.html>.

Sandal, L.K., S.I. Steinshamn, and A. Hoff. 2007. Irreversible Investments Revisited. $M a-$ rine Resource Economics 22:255-66.

Scott, A. 1955. The Fishery: The Objectives of the Sole Owner. Journal of Political Economy 63:116-24.

Singh, R., Q. Weninger, and M. Doyle. 2006. Fisheries Management with Stock Growth Uncertainty and Costly Capital Adjustment. Journal of Environmental Economics and Management 52:582-99.

Smith, V.L. 1968. Economics of Production from Natural Resources. American Economic Review 58:409-31. 1969. On Models of Commercial Fishing. Journal of Political Economy 77:181-98.

Squires, D., M. Alauddin, and J. Kirkley. 1994. Individual Transferable Quota Markets and Investment Decisions in the Fixed Gear Sablefish Industry. Journal of Environmental Economics and Management 27:185-204.

Sumaila, U.R. 1995. Irreversible Capital Investment in a Two-stage Bimatrix Fishery Game Model. Marine Resource Economics 10:263-84.

Townsend, R.E. 1985. On "Capital-stuffing" in Regulated Fisheries. Land Economics 61:195-97.

Ward, J.M., and J.G. Sutinen. 1994. Vessel Entry-exit Behaviour in the Gulf of Mexico Shrimp Fishery. American Journal of Agricultural Economics 76:916-92.

Weninger, Q., and R.E. Just. 2002. Firm Dynamics with Tradable Output Permits. American Journal of Agricultural Economics 84:572-84. 
Renewable Reental Economics 'hnical paper no. s of Bioeconom-

Resource Manies in European eds. Portsmouth,

The First Steps. eries Economics

Optimal Periodic 42:47-67.

1ery under Alteri.

and Economics, le Development. Practice. Marine stion Devices in urce Economics

Jecisions of the Available online is Revisited. $M a-$ "nal of Political th Stock Growth sntal Economics srican Economic omy 77:181-98. : Quota Markets rnal of Environ3imatrix Fishery and Economics Gulf of Mexico ;-92.

Permits. Ameri-
Weninger, Q., and K.E. McConnell. 2000. Buyback Programs in Commercial Fisheries: Effciency versus Transfers. Canadian Journal of Economics 33:394-412.

Wilen, J.E. 1976. Common Property Resources and the Dynamics of Over-exploitation: The Case of the North-Pacific Fur Seal. Paper $n^{\circ} 3$ in the Programme in Resource Economics, Department of Economics, The University of British Columbia, Vancouver, Canada. 